\title{
ANALYSIS OF FISH SPECIES COMPOSITION IN MIAZGA - A STREAM BLOCKED WITH A SMALL DAM RESERVOIR (PILICA RIVER BASIN, CENTRAL POLAND)
}

\author{
1Department of Hydrobiology, Ichthyology and Biotechnology of Breeding, \\ West Pomeranian University of Technology, Szczecin, Poland \\ ${ }^{2}$ Department of Ecology and Vertebrate Zoology, University of Lodz, Poland
}

\begin{abstract}
A study of fish species composition was performed in the stream Miazga, blocked with a dam without a fish ladder, located in the Pilica river basin. Three sites above and two below the reservoir were selected. The presence of 13 species of fish and one species of lamprey in larval stage was found. The most abundant species were perch Perca fluviatilis, gudgeon Gobio gobio and Prussian carp Carassius gibelio. The presence of three new species of fish was noted: common brown bullhead Ameiurus nebulosus, eel Anguilla anguilla and orfe Leuciscus idus. The analysis of species evenness indicated that the number of species and their abundance at all research sites were close to maximum. Relatively low value of the dominance index indicated that the examined fish assemblages were not strongly dominated by a single species, which was confirmed by the diversity index. The differences in the composition of the fish fauna at sites above and below the dam reservoir were not sufficiently pronounced in the cluster analysis, however from the historical point of view, the structure of fish assemblage in the stream has changed. Shift in the fish assemblage composition may be affected to the pollution of the stream, stocking activities and escaping from the fish farms.
\end{abstract}

Key words: Miazga stream, central Poland, dam reservoir, fish fauna, biotic indices.

\section{INTRODUCTION}

The river is a continuous watercourse, where successive regions occur with specific characteristics - the amount of biomass, flow rate, substrate etc. Construction of dams and their reservoirs on rivers causes disturbance of the existing equilibrium of the river ecosystems (Vannote et al. 1980; Bednarek 2001; Bartel et al. 2007). It not only affects the river downstream of the dams, but also surrounding the dams. Dams produce several impacts on river ecosystems: they prevent free migration of fish (both down-the river and upstream), alter the natural cycle of flow, transform the biological and physical characteristics of river channels and floodplains, and fragment the continuity of rivers. of benthic fauna and of sediments. Furthermore, dams and the associated reservoirs can cause an increase in water temperature in the river downstream of the dam, which affects, among others, the development of larvae of aquatic insects (an important component of fish food) - Kurzawski (2012). The change from a river to a reservoir ecosystem often affects species composition.

Corresponding author: Beata Więcaszek, Department of Hydrobiology, Ichthyology and Biotechnology of Breeding, West Pomeranian University of Technology, Szczecin, Kazimierza Królewicza 4, 71-550 Szczecin, Poland, e-mail: Beata.Wiecaszek@zut.edu.pl 
The main reasons of reservoir construction is flood control, water storage for industry and agriculture, energy production, recreational functions and fish culture (Wiatkowski et al. 2007; Traczewska 2012). In Poland, many large dams were built on mighty rivers. After the "Flood of the Millennium" in 1997, it was found that small reservoirs situated in the foothills and mountain sections of small rivers, worked better in retaining flood waves than the large lowland reservoirs. However, impacts of dam reservoirs on small river ecosystem are poorly documented as compared to those on large river ecosystems (Wiatkowski et al. 2007). Therefore the surveys of fish fauna in the small rivers blocked with dam reservoir are urgently needed (Woody 2010).

We carried this research out at the Miazga River, which is a left tributary of the Wolbórka River (belonging to the Pilica River system see Fig. 1) and flows to it at an altitude of $185 \mathrm{~m}$ above sea level, at $17 \mathrm{~km}$ of its course. It originates on the south-western outskirts of the city of Łódz, at an altitude of $235 \mathrm{~m}$.a.s.l. Miazga is $27 \mathrm{~km}$ long, of width ranged within 2-4 m, and depth from 30 to $80 \mathrm{~cm}$ (with deep pools of $120 \mathrm{~cm}$ ), with an average gradient $1.85 \mathrm{~m} \mathrm{~km}^{-1}$. Kotliny Reservoir, created in 1977, is located in the lower reaches of the river. It has a total capacity of $334,000 \mathrm{~m}^{3}$ and an area of 22 ha, in the shape of a triangle with an island in the middle; an average depth is $1.2 \mathrm{~m}$ while maximum is $3 \mathrm{~m}$. There is no hydropower on the dam; its purpose is to lower the risk of a flood and recreational fishing (Dąbrowski 2008). The stream flows the entire length through a treeless valley of the Łódź Upland (Kondracki 1998), through the farmlands in the upper course, and in the middle and lower reaches it cuts through alder woodlands and riparian meadow bands (Penczak 1963).

The substrate on the bottom is mostly organic with contribution of sands and gravels, detritus is present in marginal and oxbow lakes. The $\mathrm{pH}$ is $6.5-8.0$ and the conductivity is $350-500 \mu \mathrm{S} / \mathrm{cm}$. These are the conditions specified for the organic stream (Błachuta et al. 2010).

Surveys of the fish fauna structure in Miazga have started in 1963 (Penczak 1963) and have been continued till 2010 (Penczak 1988; Penczak et al. 2007; Marszał et al. 2010), however Marszał et al. (2010) examined the fish fauna only in the area of Łódź. Penczak et al. (1995) have stated a continuous deterioration of the stream; since its course and banks were regulated, whereas surrounding areas were drained. The number of fish species and their abundance decreased, too. Even the roach Rutilus rutilus, which exhibits increasing abundance in all kind of water basins, shows a declining trend in Miazga (Penczak et al. 2007).

The aim of the study was to analyze fish species composition in the stream Miazga, blocked with the dam reservoir, and compare the results with those available in the literature (before and after the dam construction) as well as to broaden the knowledge of the influence of small dam reservoirs on the environment of small river.

\section{MATERIAL AND METHODS}

Fish were harvested in the stream Miazga in May and August 2007, by electrofishing using a generator producing three-phase, half-wave, straight direct current $(220 \mathrm{~V}, 3 \mathrm{~kW}$, $50 \mathrm{~Hz}$ ). After the research fish were released back to the water. The electrofishing sampler moved against the water current along the shore on a distance of $100 \mathrm{~m}$ (Penczak 1988, 1989). 
In order to determine impacts of dam on the fish fauna structure, 5 research sites were selected - 3 upstream the reservoir: Bedoń (Bed), Bukowiec (Buk) and Kurowice (Kur), and 2 downstream the reservoir: Dalków (Dal) and Zamość (Zam) - Fig.1. Miazga at sites Bukowiec and Dalków, is a narrow watercourse, while widening at sites Bedoń, Kurowice and Zamość (Table 1).

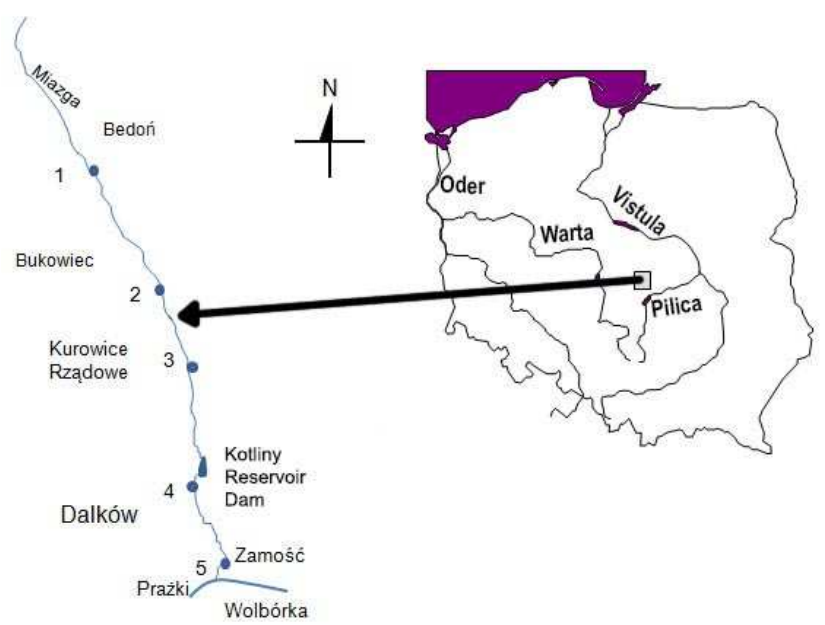

Fig.1. Samplings sites on the map of region

Table 1. Morphometry of site locations on the stream Miazga (followed Penczak et al. 2007 and own studies)

\begin{tabular}{|c|c|c|c|c|c|c|}
\hline \multicolumn{2}{|c|}{ Number of site and village } & 1 - Bedoń & 2 - Bukowiec & 3 - Kurowice & 4 - Dalków & 5 - Zamość \\
\hline \multicolumn{2}{|c|}{$\begin{array}{l}\text { Distance from the mouth } \\
{[\mathrm{km}]}\end{array}$} & 16.2 & 11.3 & 8.2 & 3.7 & 0.6 \\
\hline \multicolumn{2}{|c|}{ Mean width [m] } & 2.0 & 3.0 & 4.0 & 3.0 & 3.0 \\
\hline \multicolumn{2}{|c|}{$\begin{array}{l}\text { Mean and maximum depth } \\
{[\mathrm{m}]}\end{array}$} & $0.5(1.2)$ & $0.4(0.6)$ & $0.8(0.8)$ & $0.5(0.8)$ & $0.3(0.7)$ \\
\hline \multicolumn{2}{|l|}{ Deep pools } & + & - & + & - & - \\
\hline \multirow{4}{*}{$\begin{array}{l}\text { Bottom } \\
\text { structure } \\
\text { (in \% of cover) }\end{array}$} & sand & 35 & 90 & 75 & 75 & 89 \\
\hline & gravel & 0 & 0 & 0 & 10 & 10 \\
\hline & stones & 0 & 10 & 10 & 0 & 3 \\
\hline & silt & 75 & 40 & 15 & 15 & 1 \\
\hline \multicolumn{2}{|c|}{$\begin{array}{l}\text { Macrophytes submerged } \\
\text { (in \% of cover) }\end{array}$} & 40 & 15 & 5 & 20 & 5 \\
\hline \multicolumn{2}{|c|}{$\begin{array}{l}\text { Macrophytes emergent in } \\
\text { the bed (in \% of cover) }\end{array}$} & 20 & 100 & 0 & 100 & 80 \\
\hline \multicolumn{2}{|c|}{$\begin{array}{l}\text { Trees along the stream } \\
\text { shore (shadow over in \%) }\end{array}$} & $-(10)$ & $+(15)$ & $+++(40)$ & $-(50)$ & $++(25)$ \\
\hline \multicolumn{2}{|c|}{ Character of stream bed } & $\mathrm{R}$ & $\mathrm{R}$ & $\mathrm{Nm}$ & $\mathrm{Rm}$ & $\mathrm{Rm}$ \\
\hline \multicolumn{2}{|c|}{ Adjacent areas } & $\mathrm{wl}$ & fy, wl & $f$, fy & fy & fy, wl \\
\hline
\end{tabular}

$\mathrm{R}$ - regulated stream bed, $\mathrm{Rm}$ - regulated but meandering stream bed, $\mathrm{Nm}$ - naturally meandering, wl wastelands, fy - feed yard, $f$ - forest, - missing, + current (present), ++ numerous, +++ very numerous.

For each locations the following biotic indices were calculated:

- Simpson's index of domination

$\mathrm{D}=\sum \mathrm{p}_{\mathrm{i}}^{2}$

where:

$\mathrm{p}_{\mathrm{i}}$ - probability of the individual presence from the i-species;

- Simpson's diversity index

$D^{\prime}=1-\sum p_{i}^{2}$ 
- Shannon-Wiener diversity index:

$H^{\prime}=-\Sigma\left(p_{i} \ln p_{i}\right)$

where:

In $p_{i}-$ natural logarithm of $p_{i}$

- Shannon-Wiener evenness index:

$J^{\prime}=H^{\prime} / I n S$ or: $J^{\prime}=\left(H^{\prime} / H_{\max }\right)$

where:

$S$ - number of species: ratio of the real species biodiversity $\left(H^{\prime}\right)$ in the collectivity studied to the potential maximal diversity $\left(\mathrm{H}_{\max }\right)$;

- Jaccard similarity coefficient:

$P_{x y}=C / A+B-C$

where:

$P_{x y}$ - faunistic similarity between $x$ and $y$,

$C$ - number of common species for $x$ and $y$,

$A$ - number of species in set $\mathrm{X}$,

$B$ - number of species in set y (Krebs 2011).

For Shannon-Wiener (J') and diversity Simpson's index (1-D) following ranges of variability are established: $x>0.8-$ high stability of group; $x=0.6-0.8-$ stabile group; $x<0.6$ - group exposed to stress (e.g. pollution, invasion of non-indigenous species).

Similarity among sites are presented on dendrograms.

Two models have been used: 1. present-absent method, and 2. by standardization (number of individuals on the site divided by the maximum number) - Mello and Buzas (1968); Milligan and Cooper (1988).

Results obtained at the site in Bukowiec was disregarded, because only one fish species (in May) was recorded there.

The domination levels were established, in the whole stream and on particular locations: eudominants (number of individuals over 10\%), dominants (5.01-10\%), subdominants (2.01-5\%), recendents (1-2\%), subrecendents (below 1\%) - Biesiadka and Kowalik (1980).

In addition, the physical and chemical water quality characteristics were determined: conductivity, oxygen saturation (in \%), quantity of dissolved oxygen $\left(\mathrm{mg} / \mathrm{dm}^{3}\right), \mathrm{pH}$ and temperature with the multi-purposed gauge MULTILINE WTW (Table 2).

Table 2. Chemical and physical parameters of Miazga stream water in 2007

\begin{tabular}{|c|c|c|c|c|c|c|c|}
\hline & \multirow{2}{*}{ Parameter } & \multirow{2}{*}{ Month } & \multicolumn{5}{|c|}{ Site } \\
\hline & & & Bedoń & Bukowiec & Kurowice & Dalków & Zamość \\
\hline \multirow{2}{*}{1.} & \multirow{2}{*}{$\mathrm{pH}$} & May & 7.34 & 7.50 & 7.91 & 8.58 & 7.87 \\
\hline & & August & 7.21 & 7.56 & 7.30 & 5.20 & 7.74 \\
\hline \multirow{2}{*}{2.} & \multirow{2}{*}{ Conductivity $\left[\mu \mathrm{S} \cdot \mathrm{cm}^{-1}\right]$} & May & 461.00 & 659.00 & 399.00 & 371.00 & 393.00 \\
\hline & & August & 433.00 & 960.00 & 434.00 & 398.00 & 408.00 \\
\hline 3. & Oxygen [mg/dm $\left.{ }^{3}\right]$ & May & 4.38 & 1.25 & 9.30 & 5.33 & 8.36 \\
\hline 4. & Oxygen saturation [\%] & May & 48.90 & 14.00 & 39.70 & 58.50 & 43.30 \\
\hline \multirow{2}{*}{5.} & \multirow{2}{*}{ Temperature } & May & 18.70 & 19.00 & 19.80 & 18.20 & 17.80 \\
\hline & & August & 14.80 & 15.00 & 13.90 & 14.70 & 14.90 \\
\hline
\end{tabular}




\section{RESULTS}

In two samplings on May 28 and August 3, 2007, 1645 individuals (13 fish species and one species of lamprey in larval ammocoete stage) were collected. The resulting domination order was: perch Perca fluviatilis L., gudgeon Gobio gobio (L., 1758), Prussian carp Carassius gibelio (Bloch, 1782), sunbleak Leucaspius delineatus (Heckel, 1843), bearded stone loach Barbatula barbatula (L., 1758), orfe Leuciscus idus (L., 1758), pike Esox lucius L., 1758, tench Tinca tinca (L., 1758), three-spined stickleback Gasterosteus aculeatus L., 1758, roach Rutilus rutilus (L., 1758), eel Anguilla anguilla (L., 1758), common brown bullhead Ameiurus nebulosus (Lesueur, 1819), ninespined stickleback Pungitius pungitius (L., 1758) and a brook lamprey Lampetra planeri (Bloch, 1784). The catch represented eight families: Anguillidae, Cyprinidae, Balitoridae, Ictaluridae, Esocidae, Gasterosteidae, Percidae, and Petromyzontidae.

The most numerous species - perch Perca fluviatilis (38.3\% of total fish number), the gudgeon $(23.1 \%)$ and Prussian carp $(11.85 \%)$ belonged also to eudominant category. Sunbleak was dominant $(6.99 \%)$, while subdominants comprised orfe and bearded stone loach (each of $4.86 \%)$, pike (3.34\%) and tench (2.43\%). Only one species was recendent three-spined stickleback (1.82\%). The remaining species belong to subrecendents: roach $(0.9 \%)$, eel $(0.61 \%)$, common brown bullhead, brook lamprey and ninespined stickleback (each of $0.3 \%$ ) - Table 3 . The comparison of the frequency of the fish species recorded at sites in this study is presented in Fig. 2.

Table 3. Total number of fish specimens at all sites, arranged by the domination in catches

\begin{tabular}{|c|c|c|c|c|c|}
\hline Species & $\mathrm{n}$ & $\begin{array}{l}\text { Percentage } \\
\text { of } n\end{array}$ & $\begin{array}{c}\text { Percentage } \\
\text { of weight }\end{array}$ & Parents care & $\begin{array}{l}\text { Breeding group } \\
\text { (Balon 1990) }\end{array}$ \\
\hline $\begin{array}{l}\text { Perch } \\
\text { Perca fluviatilis }\end{array}$ & 630 & 38.30 & 30.21 & no & phyto-lithophils \\
\hline $\begin{array}{l}\text { Gudgeon } \\
\text { Gobio gobio }\end{array}$ & 380 & 23.10 & 14.24 & no & psamnophils \\
\hline $\begin{array}{l}\text { Prussian carp } \\
\text { Carassius gibelio }\end{array}$ & 195 & 11.85 & 7.95 & no & phytophils \\
\hline $\begin{array}{l}\text { Sunbleak } \\
\text { Leucaspius delineatus }\end{array}$ & 115 & 6.99 & 0.56 & yes & phytophils \\
\hline $\begin{array}{l}\text { Orfe }^{a} \\
\text { Leuciscus idus }\end{array}$ & 80 & 4.86 & 14.36 & no & phyto-lithophils \\
\hline $\begin{array}{l}\text { Bearded stone loach } \\
\text { Barbatula barbatula }\end{array}$ & 80 & 4.86 & 1.99 & no & psamnophils \\
\hline $\begin{array}{l}\text { Pike } \\
\text { Esox lucius }\end{array}$ & 55 & 3.34 & 8.35 & no & phytophils \\
\hline $\begin{array}{l}\text { Tench } \\
\text { Tinca tinca }\end{array}$ & 40 & 2.43 & 1.52 & no & phytophils \\
\hline $\begin{array}{l}\text { Three-spined stickleback } \\
\text { Gasterosteus aculeatus }\end{array}$ & 30 & 1.82 & 0.06 & yes & ariadnophils \\
\hline $\begin{array}{l}\text { Roach } \\
\text { Rutilus rutilus }\end{array}$ & 15 & 0.91 & 0.03 & no & phyto-lithophils \\
\hline $\begin{array}{l}\text { Eel }^{a} \\
\text { Anguilla anguilla }\end{array}$ & 10 & 0.61 & 20.39 & no & pelagophils \\
\hline $\begin{array}{l}\text { Common brown bullhead } \\
\text { Ameiurus nebulosus }\end{array}$ & 5 & 0.30 & 0.26 & yes & speleophil \\
\hline $\begin{array}{l}\text { Brook lamprey } \\
\text { Lampetra planeri }\end{array}$ & 5 & 0.30 & 0.07 & no & lithophils \\
\hline $\begin{array}{l}\text { Ninespined stickleback } \\
\text { Pungitius pungitius }\end{array}$ & 5 & 0.30 & 0.01 & yes & ariadnophils \\
\hline
\end{tabular}

$\mathrm{n}$ - number of fish; ${ }^{a}$ fish species introduced by human activities. 
A

Bedoń [\%n]

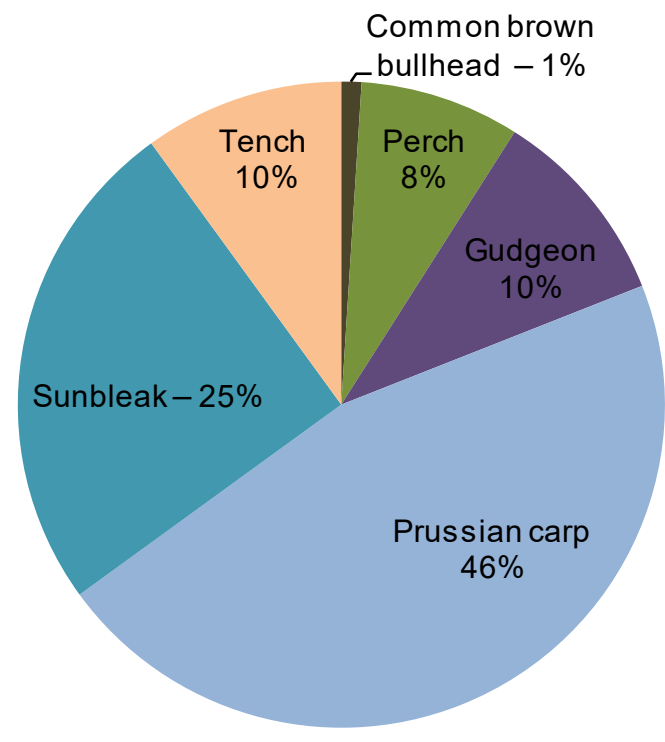

C

Dalków [\%n]

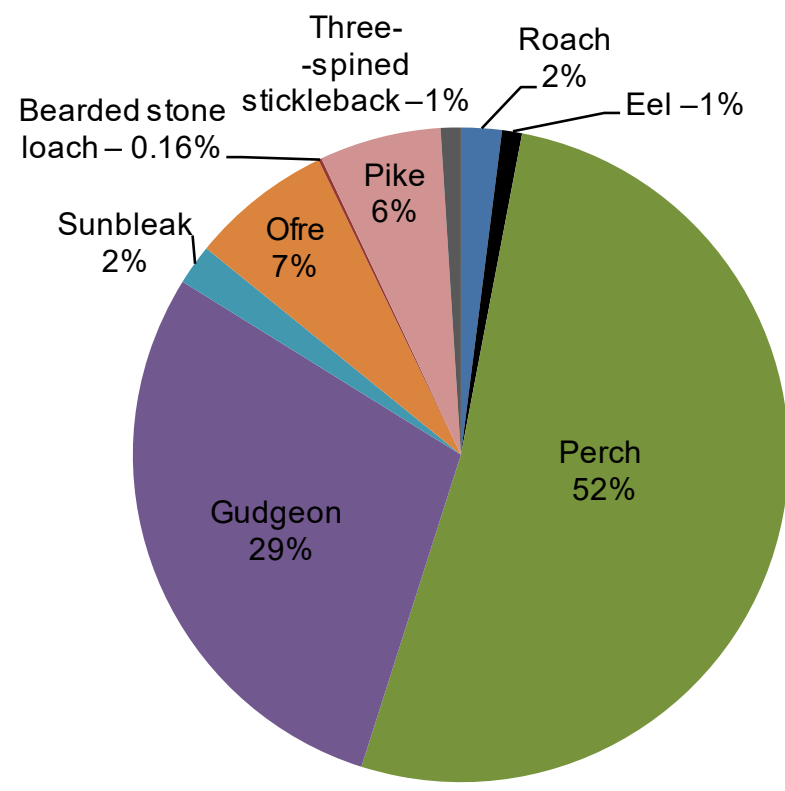

B

Kurowice $[\% n]$

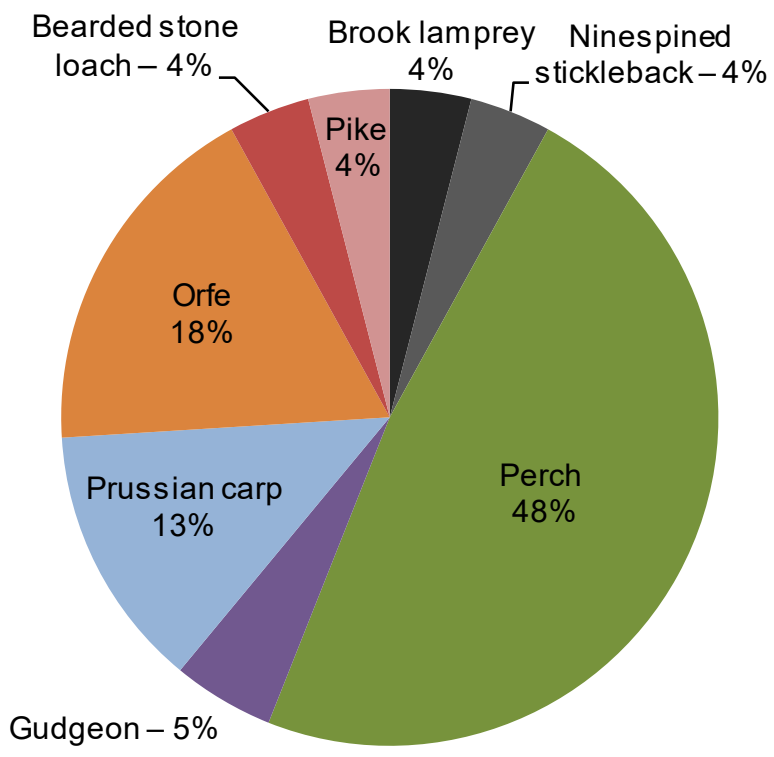

D Zamość [\%n]

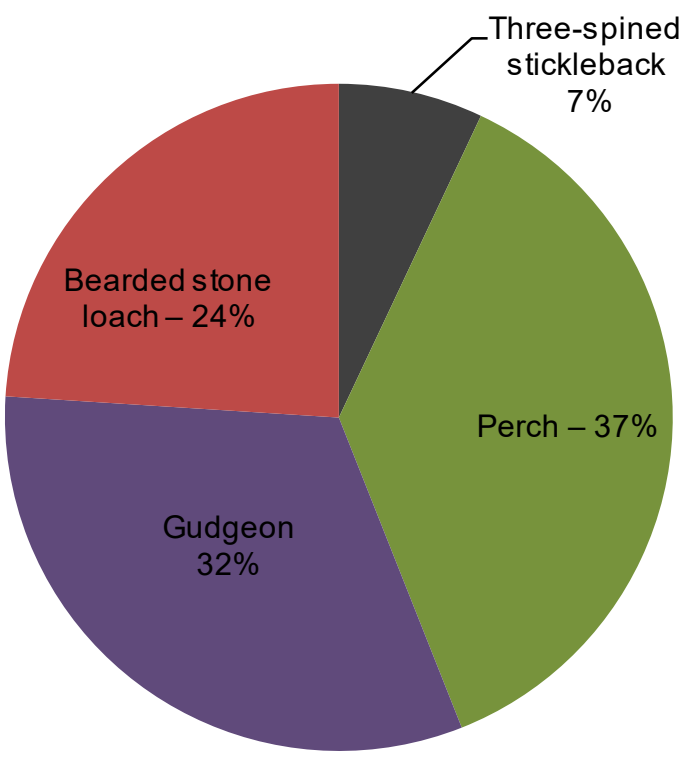

Fig. 2. Comparison of the frequency of fish species recorded at the fishing sites

At first site in Bedoń, upstream the dam, six fish species were represented by 395 specimens (195 specimens collected in May and 200 in August). The site is situated close to the fish farm, from which fish escape to the river. Eudominants comprised: Prussian carp, sunbleak, tench and gudgeon, while perch was dominant. The common brown bullhead was recorded only in August (Fig. 2A, Table 4). 
Table 4. Comparison of the fish species noted at the sites in May and August arranged by the domination in catches

\begin{tabular}{|c|c|c|c|c|c|c|c|c|c|c|}
\hline \multirow{2}{*}{$\begin{array}{l}\text { No. of site and village } \\
\text { Species }\end{array}$} & \multicolumn{2}{|c|}{ Bedoń } & \multicolumn{2}{|c|}{ Bukowiec } & \multicolumn{2}{|c|}{ Kurowice } & \multicolumn{2}{|c|}{ Dalków } & \multicolumn{2}{|c|}{ Zamość } \\
\hline & 05 & 08 & 05 & 08 & 05 & 08 & 05 & 08 & 05 & 08 \\
\hline Perch & $\mathrm{X}$ & $X$ & - & - & $x$ & $x$ & $x$ & $X$ & $X$ & $\mathrm{X}$ \\
\hline Gudgeon & $\mathrm{X}$ & $\mathrm{X}$ & - & - & $x$ & - & - & $\mathrm{X}$ & $\mathrm{X}$ & $\mathrm{X}$ \\
\hline Prussian carp & $\mathrm{X}$ & $X$ & - & - & $x$ & - & - & - & - & - \\
\hline Sunbleak & $\mathrm{X}$ & $x$ & - & - & - & - & $x$ & - & - & - \\
\hline Orfe & - & - & $\mathrm{X}$ & - & $x$ & $\mathrm{x}$ & - & $X$ & - & - \\
\hline Bearded stone loach & - & - & - & - & $x$ & - & - & $X$ & $X$ & $\mathrm{X}$ \\
\hline Pike & - & - & - & - & $x$ & - & $x$ & $x$ & - & - \\
\hline Tench & $X$ & $\mathrm{X}$ & - & - & - & - & - & - & - & - \\
\hline Three-spined stickleback & - & - & - & - & - & - & - & $X$ & $X$ & $\mathrm{X}$ \\
\hline Roach & - & - & - & - & - & - & - & $x$ & - & - \\
\hline Eel & - & - & - & - & - & - & - & $\mathrm{X}$ & - & - \\
\hline Common brown bullhead & - & $\mathrm{X}$ & - & - & - & - & - & - & - & - \\
\hline Brook lamprey & - & - & - & - & - & $\mathrm{x}$ & - & - & - & - \\
\hline Ninespined stickleback & - & - & - & - & - & $x$ & - & - & - & - \\
\hline
\end{tabular}

05 - catches in May, 08 - catches in August, - absent, $X$ - present.

At the Bukowiec site, upstream the dam, only five specimens of orfe were collected (in May). The site is under anthropogenic pressure, manifested by the strong pollution of water (most probably caused by domestic sewage draining into the river by residents - pers. comm.). At this site the conductivity in May reached $659 \mu \mathrm{S}$, and $960 \mu \mathrm{S}$ in August, which exceeded by more than $100 \%$ the value of conductivity at other sites. Lack of oxygen in the water was recorded during fish harvesting in August, while in May a very low water saturation was noted $-14 \%\left(1.25 \mathrm{~g} / \mathrm{dm}^{3}\right.$ of oxygen $)$ - Table 2 .

At the Kurowice site, upstream the dam, eight fish species were represented by 115 specimens (70 specimens collected in May and 45 in August) - Fig. 2B. It was the widest site with most numerous hiding places for fish - reeds, branches lying in the water and trees; it was located at the river stretch flowing through deciduous forest. Many hiding places did not reflect the fish abundance. Three species were eudominants: perch, orfe and Prussian carp. The remaining five species were subdominants - pike, gudgeon, brook lamprey, ninespined stickleback and bearded stone loach. Four species: gudgeon, Prussian carp, bearded stone loach and pike were noted only in May, while brook lamprey and ninespined stickleback only in August (Table 4).

At the site in Dalków, downstream the dam, a total of 860 specimens of eight species was collected (145 specimens in May and 715 in August) - Fig. 2C. The site is situated in the area of agriculture, with flows from the fields. The presence of hiding places here (vascular aquatic plants), probably resulted in the highest abundance of fish, with eudominants - perch (species of the biggest per cent ratio at the single site) and gudgeon, which constituted over $80 \%$ of the whole fish number and were noted both in May and August. Orfe and pike were dominants. The sunbleak was recorded only in May, while gudgeon, bearded stone loach, three-spined stickleback, roach and eel - only in August (Table 4). 
Table 5. Values of the biotic indices for particular sites

\begin{tabular}{|c|c|c|c|c|c|c|c|c|c|c|c|c|c|c|c|c|}
\hline Biotic index & Bed-05 & Bed-08 & Bed & Buk-05 & Buk & Kur-05 & Kur-08 & Kur & Dal-05 & Dal-08 & Dal & Zam-05 & Zam-08 & Zam & Upstream & Downstream \\
\hline $\begin{array}{l}\text { D Simpson's index } \\
\text { of domination }\end{array}$ & 0.360 & 0.283 & 0.297 & 1 & 1 & 0.316 & 0.333 & 0.285 & 0.529 & 0.363 & 0.361 & 0.303 & 0.412 & 0.309 & 0.224 & 0.328 \\
\hline $\begin{array}{l}\text { 1-D Simpson's } \\
\text { diversity index }\end{array}$ & 0.640 & 0.717 & 0.703 & 0 & 0 & 0.684 & 0.667 & 0.715 & 0.471 & 0.637 & 0.639 & 0.697 & 0.588 & 0.692 & 0.776 & 0.672 \\
\hline $\begin{array}{l}\text { H 'Shannon- } \\
\text {-Wiener index }\end{array}$ & 0.545 & 0.619 & 0.617 & 0 & 0 & 0.621 & 0.528 & 0.697 & 0.355 & 0.554 & 0.581 & 0.543 & 0.451 & 0.539 & 0.767 & 0.622 \\
\hline $\begin{array}{l}\text { J' Shannon-Wiener } \\
\text { evenness index }\end{array}$ & 0.780 & 0.795 & 0.793 & 1 & 1 & 0.798 & 0.876 & 0.771 & 0.744 & 0.614 & 0.609 & 0.902 & 0.748 & 0.896 & 0.736 & 0.651 \\
\hline Number of species & 5 & 6 & 6 & 1 & 1 & 6 & 4 & 8 & 3 & 8 & 9 & 4 & 4 & 4 & 11 & 9 \\
\hline
\end{tabular}

The bold font indicates the total values for the site (from May and August).

Other explanations see Fig. 3. 
At the site in Zamość, downstream the dam, a total of 345 specimens of four species was collected (260 specimens in May and 85 in August) - Fig. 2D. Three most abundant species (perch, gudgeon and bearded stone loach) constituted to approximately $92.5 \%$ of the fish number. The dominant species, three-spined stickleback constituted to $7.4 \%$. All species were recorded both in May and August (Table 4).

The values of biotic indices are presented in Table 5. The Simpson's index of domination (D) was the highest for site Dal-05, pointed to one species - perch, as markedly dominant. The Simpson diversity index (1-D) and Shannon-Wiener index ( $\left.H^{\prime}\right)$ at most sites showed high level of diversity. At all sites level of the Shannon-Wiener evenness index ( $J$ ') was high indicating the number of species was close to the maximal one; the highest level was noted at sites Zam-05 and Kur-08. At most of sites the biotic index pointed to the stability of the fish fauna assemblages, however the stronger stability was found for sites upstream the reservoir. When the biotic indices were analyzed, disregarding the time of the survey, the Shannon-Wiener evenness index (J') pointed to the bigger fulfilment of niches below the dam. At most of the sites the biotic indices pointed to the stability of the fish fauna assemblages. However exposition to the stress was noted the downstream of reservoir - at the Dalków and Zamość sites.

Table 6. Results for the Jaccard's Index on the heterogeneity of sites

\begin{tabular}{cccccc}
\hline No. of site & 1 & 2 & 3 & 4 & 5 \\
\hline 1 & $\mathrm{x}$ & 0.00 & 0.43 & 0.40 & 0.40 \\
\hline 2 & 0.00 & $\mathrm{x}$ & 0.22 & 0.20 & 0.00 \\
\hline 3 & 0.43 & 0.22 & $\mathrm{x}$ & 0.47 & 0.50 \\
\hline 4 & 0.40 & 0.20 & 0.47 & $\mathrm{x}$ & 0.62 \\
\hline 5 & 0.40 & 0.00 & 0.5 & 0.62 & $\mathrm{x}$ \\
\hline
\end{tabular}

1 - Bedoń, 2 - Bukowiec, 3 - Kurowice, 4 - Dalków, 5 - Zamość.

A comparison of the sites with regard to the Jaccard's Index is presented in Table 6. The highest level of similarity was noted between Dalków and Zamość (sites downstream the dam). In Fig. 3 data are ordered as 0 or 1, i.e. the species is present or absent at the site. Fig. 3 demonstrates two groups of sites - one including the sites above the dam, and one those sites below the dam. However, amongst the group of sites above the dam, Dalków is included (Dal-05), while amongst the group of sites below the dam - Kurowice (Kur-05). Figure 4 shows the standardized number of species at sites (with regard to the site with the highest abundance of individuals). In the Fig. 4 the similarity dendrogram of sites according to the standardized number of fish at sites located upstream and downstream the dam may give rise to different interpretations. The differences in the composition of the fish fauna at sites located above and below the dam reservoir are not sufficiently pronounced in the cluster analysis (Fig. 3, Fig. 4). 


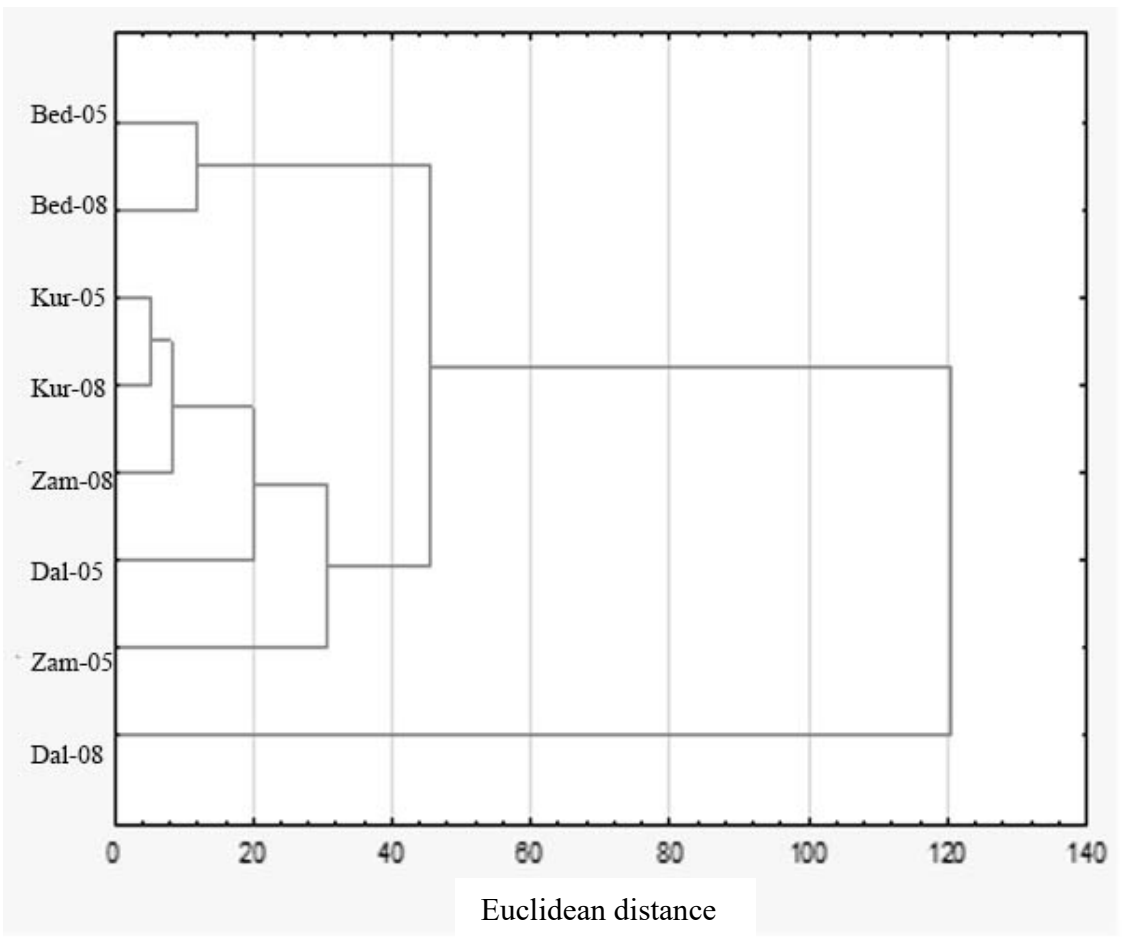

Fig. 3. Similarity dendrogram of sampling sites according to the presence or absence of species based upon catches during May and August 2007 by electrofishing in Miazga River

Bed-05 - Bedoń in May 2007, Bed-08 - Bedoń in August 2007, Kur-05 - Kurowice in May 2007, Kur-08 Kurowice in August 2007, Dal-05 - Dalków in May 2007, Dal-08 - Dalków in August 2007, Zam-05 - Zamość in May 2007, Zam-08 - Zamość in August 2007.

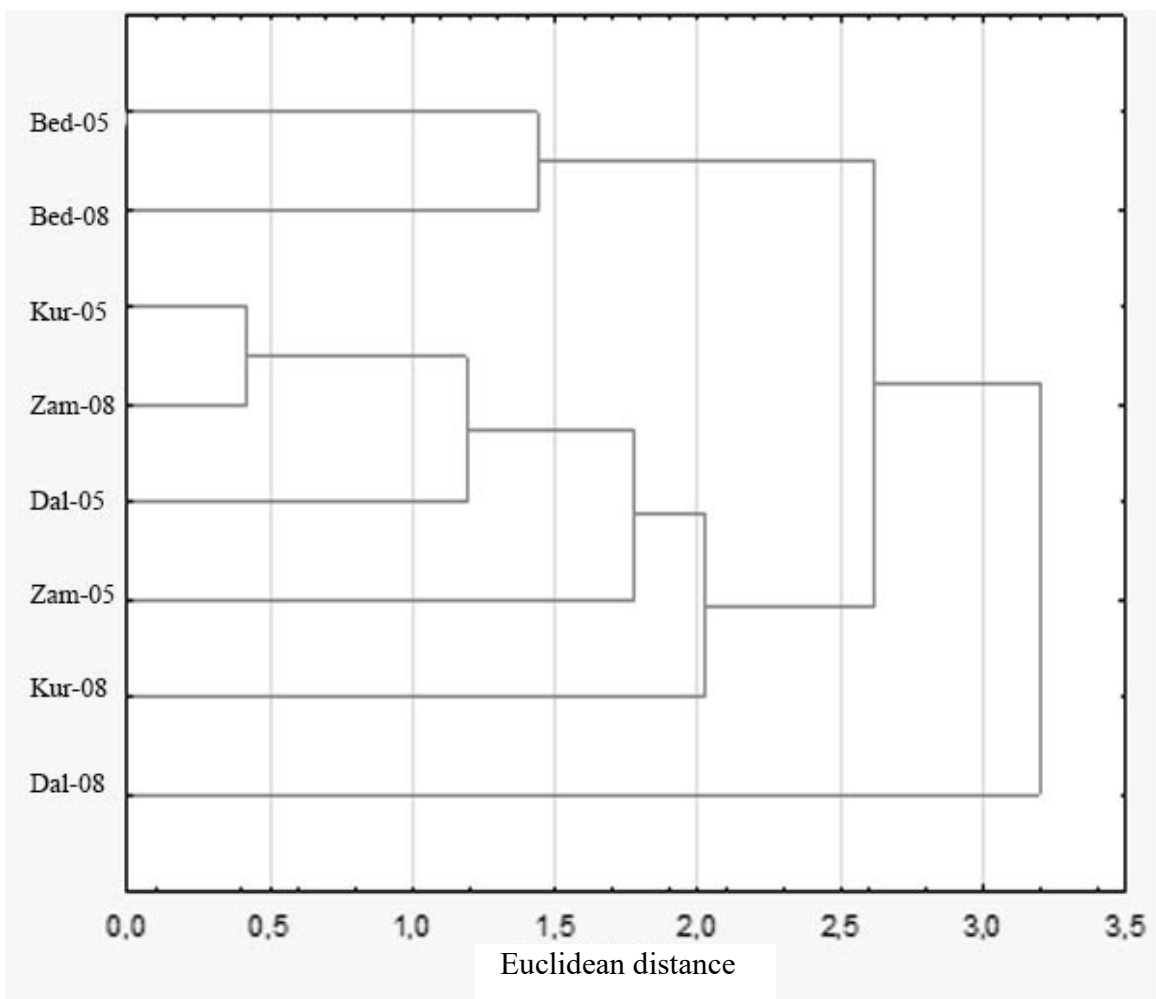

Fig. 4. Similarity dendrogram of sites according to the standardized number of fish based upon catches during May and August 2007 by electrofishing in Miazga River

Explanations see Fig. 3. 


\section{DISCUSSION}

Analysis of the Kotliny Reservoir influence on fish species composition can be carried out by comparing the results of electrofishing in 1963 and 1964 (stream not blocked by the dam reservoir), with results obtained in 1985, 1992, 2005 and 2007 (stream blocked by the dam reservoir). During over four decades of research, from 1963 to 2007, in Miazga stream, 21 fish species and one species of lamprey were recorded (Fig. 5). The species number oscillated between 8-9 (in 1992 and 1963) to 14-16 species (in 1985, own study and 1964). When compared the number of species in Miazga in 1964 (Penczak 1988) and in 2007 (own study), it revealed that downstream the dam the number species was constant (9 species), while upstream it decreased from 14 to 11 . The structure of fish fauna has significantly changed; below the dam four species disappeared: dace Leuciscus leuciscus, brook lamprey Lampetra planeri, burbot Lota lota, and bleak Alburnus alburnus. Gudgeon Gobio gobio and perch Perca fluviatilis populations increased in abundance, while roach Rutilus rutilus and pike Esox lucius populations became less abundant. Upstream of the dam the three-spined stickleback Gasterosteus aculeatus, burbot Lota lota, weatherfish Misgurnus fossilis, roach Rutilus rutilus, crucian carp Carassius carassius and carp Cyprinus carpio disappeared. The Prussian carp Carassius gibelio, tench Tinca tinca and perch Perca fluviatilis became more abundant, while gudgeon Gobio gobio, brook lamprey Lampetra planeri, sunbleak Leucaspius delineatus, pike Esox lucius, and bearded stone loach Barbatula barbatula populations decreased (Fig. 5).

As native species, noted throughout the decades of research in Miazga, the gudgeon Gobio gobio, perch Perca fluviatilis, roach Rutilus rutilus, bearded stone loach Barbatula barbatula and pike Esox lucius can be considered. Furthermore, a retrospective analysis (1963-2007) of the fish species composition in Miazga and Wolbórka (a parent river), exhibited the occurrence of the same species (Penczak 1963, 1988, 1989; Penczak et al. $1995,2007)$. The status of the roach population is questionable in the Miazga stream. Its abundance in the Kotliny reservoir is high, however during this study, it was absent at sites above the reservoir. Analysis of data available in the literature exhibited high fluctuations in roach population abundance over years (Fig. 5). The individuals of roach found downstream of the reservoir are likely to be migrants from Wolbórka river, where the population is stable (Penczak et al. 2007). The bleak, ruffe, brown bullhead, eel, carp, tench, crucian carp, dace (Fig. 5) and bittering (Penczak 1989) were noted only at single sites in Miazga.

In this study, at the site in Bedoń, when compared to the previous years, pike disappeared, while the population of the currently noted species increased. Figures 3 and 4 show the clear separation of Bedon from the remaining sites, probably resulted from the presence of fish farm nearby. The tench, common brown bullhead, Prussian carp (noted at the Bedoń site for the first time) and sunbleak are likely escapees from the fish pond situated nearby.

At the site in Bukowiec, all species noted previously, disappeared. At the site in Kurowice, perch, Prussian carp and gudgeon exhibited increasing abundance in recent years. Burbot disappeared, orfe and ninespined stickleback occurred, while brook lamprey was noted again. At the site in Dalków the abundance of eudominants - perch and gudgeon increased markedly in recent years, and the three-spined stickleback and sunbleak occurred. 


\begin{tabular}{|c|c|c|c|c|}
\hline $\begin{array}{l}\text { Site and year of } \\
\text { study } \rightarrow\end{array}$ & $\begin{array}{c}\mathrm{A} \\
1963\end{array}$ & $\begin{array}{c}B \\
1964\end{array}$ & $\begin{array}{c}C \mathrm{C} \\
2005\end{array}$ & $\begin{array}{c}D \\
2007\end{array}$ \\
\hline & \begin{tabular}{|l|l|l|}
2 & 3 & 4 \\
\end{tabular} & \begin{tabular}{l|l|l|l|l|}
1 & 2 & 3 & 4 & 5 \\
\end{tabular} & \begin{tabular}{l|l|l|l|l|}
1 & 2 & 3 & 4 & 5 \\
\end{tabular} & \begin{tabular}{|l|l|l|l|l}
1 & 2 & 3 & 4 & 5 \\
\end{tabular} \\
\hline Brook lamprey & & & & \\
\hline Eel & & & & \\
\hline Bleak & & & & \\
\hline Crucian carp & & & & \\
\hline Prussian carp & & & & \\
\hline Carp & & & & \\
\hline Gudgeon & & & & \\
\hline Sunbleak & & & & \\
\hline Orfe & & & & \\
\hline Dace & & & & \\
\hline Roach & & & & \\
\hline Tench & & & & \\
\hline Weatherfish & & & & \\
\hline $\begin{array}{l}\text { Bearded stone } \\
\text { loach }\end{array}$ & & & & \\
\hline $\begin{array}{l}\text { Common } \\
\text { brown bullhead }\end{array}$ & & & & \\
\hline Pike & & & & \\
\hline Burbot & & & & \\
\hline $\begin{array}{l}\text { Three-spined } \\
\text { stickleback }\end{array}$ & & & & \\
\hline $\begin{array}{l}\text { Ninespined } \\
\text { stickleback }\end{array}$ & & & & \\
\hline Ruffe & & & & \\
\hline Perch & & & & \\
\hline
\end{tabular}

Fig. 5. Results of electrofishing in the Miazga stream from the historical point of view 1 - Bedoń, 2 - Bukowiec, 3 - Kurowice, 4 - Dalków, 5 - Zamość, A - Penczak (1963), B - Penczak (1988), C - Penczak et al. (2007), D - Own study. 
This is the only site, where the roach is noted (approximately at the same level as in previous years). At the site in Zamość, the increase of abundance was noted only in case of perch. The stable abundance was noted in the gudgeon and bearded stone loach population, while the decrease of abundance was recorded in the ninespined and three-spined sticklebacks. The roach has disappeared. The eel individuals, recorded for the first time in August 2007, were either migrants from Wolbórka, where they have been already noted (Penczak et al. 2007), or they came from the reservoir Kotliny, which was stocked with this species. Similarly, the orfe noted at sites upstream the reservoir could come from the Kotliny reservoir, which was stocked with this species by Polish Anglers Association in 2000 and 2003 (pers. comm.).

Perch was noted at all sites both in May and August, except the Bukowiec. This species dominated the Kurowice, Dalków and Zamość sites, while in Bedoń, situated close to the fish farm, Prussian carp became a dominant species. Perch, eudominant in this study, is a common fish species in many Central European rivers. This species typically become more abundant with progressive river eutrophication (Kruk 2007; Syvaranta and Jones 2008). Eurytopic fish were frequent, while the phyto-lithophilic (perch) and phytophilic species (Prussian carp, sunbleak, pike, tench) dominated. High abundance of perch and other eurytopic species indicates a worsening of the Miazga stream condition according to the European Fish Index (EFI+_PL) criteria (Adamczyk et al. 2013).

Construction of the dam on Miazga only with an overflow outlet prevents the free migration of fish down and up the river. This situation is known for all reservoirs in the world (Wiatkowski et al. 2007) and only the installation of fish migration aids such as fishpasses or bypasses allow them to migrate. However, installation of fish passes on dams do not always significantly improve fish populations because several species are either too large or too small to use the devices (Bednarek 2001; Bartel et al. 2007; Kurzawski 2012). Such a construction in the case of Kotliny Reservoir seems to be not possible due to small size of Miazga and the size of the dam. Petts (1984); Allan (1998); Kajak (1998); Kawecka and Eloranta (1994) indicated the negative impact of a reservoir on the transparency of water and the rhythm of flows which causes a loss of contact with the floodplains. Pietraszewski et al. (2008) indicated human pressures (river fragmentation, pollution), as the main drivers for the reduction of the number of rheophilic species and their abundance in Sanna River. In the stream Miazga, due to the slow water current at most sites, the presence of valuable rheophilic fish is very scarce (only gudgeon, bearded stone loach and orfe). Dace and burbot disappeared (Penczak et al. 2007). Rheophilic fish belong to the organisms that respond quickly to deteriorating environmental conditions. Disappearance of these species may be a signal of unfavourable changes in the environment affecting the biological balance (Schiemer et al. 2003).

According to some authors (Zalewski and Frankiewicz 1994; Ekosystem zbiornika Siemianówka... 2006; Zubala 2009), presence of the reservoir (regardless of the size) also brings positive aspects related to water purification from biogenic substances, which are accumulated in bottom sediments, acting as a settler. In this study it was confirmed by the decreased level of conductivity at sites downstream the reservoir. The dam reservoir also improves the additional (artificial) oxygenation of water in the river below the dam. According 
to Buras et al. (2007) there are also such positive aspects as enlargement of the spawning grounds for phytophilic fish (such as pike, a valuable game fish) in the area of the newly formed water reservoir. Penczak et al. (1995) and Wiśniewolski et al. (2004) confirmed that the dam reservoir is an excellent breeding ground for many fish species which can migrate upstream the river. Pietraszewski et al. (2008) claimed that the occurrence of new species is also a positive phenomenon. In Miazga, downstream the dam, four new species appeared (three-spined stickleback, sunbleak, orfe and eel), while upstream the dam three species occurred (ninespined stickleback, orfe, common brown bullhead). It should be considered that they are likely to be migrants from the fish ponds or come from the stocking activities.

On the other hand there are different possibilities to improve the quality of a stream ecosystem; according to Water Frame Directive, the stream restoration for water quality improvement should consider the restoration of the ecological integrity of the whole ecosystem. The first step in stream restoration, according to Guidelines for the integrated... (2002) is to restore natural stream morphology, such as flow, depth, substrate and cover, both instream and riparian, that provide fish habitat and comprise the physical attributes of the riverine ecosystem.

It seems that the large reservoirs, such as Siemianówka (Ekosystem zbiornika Siemianówka... 2006) or Włocławek Reservoir, due to their depth or size cause much stronger disturbances in the bottom layer of the river (Dukowska 2000). Small reservoirs, such as Wióry or Kotliny affect the ecosystem of the river negatively, but the scale of their impact is much smaller (Buras et al. 2007; Wiatkowski et al. 2007). Analysis of the impact of a small dam reservoir on a small river, even though already postulated by Wiatkowski et al. (2007) is conducted very rarely (Zubala 2009). Franssen and Tobler (2013) analyzed the impact of dam reservoir on fish fauna of the Little River (Oklahoma, USA). They found that fish fauna at sites above the reservoir was comparable to that from before 45 years, while below the reservoir, $\mathrm{n}$ a significantly worse condition was observed, like in the Edwards Dam in Maine where a serious decline in numerous fish species was noted within the Kennebec River due to the blocking migration and diminishing suitable spawning habitat. Recognition of these impacts has led to a search for solutions - over 100 small dams have been removed within the United States and many others are being considered for removal (Wood 1999). In Denmark several small dams were removed and the habitat was improved (Iversen et al. 1993). In Slovakia, the problem with the preservation of continuity of the flow is reported by Jurik et al. (2015), who stated that the tradition of building water reservoirs is not a solution of the recent times. The design of small water reservoirs in Slovakia and neighbouring countries has common origins in the middle of the last century. The safety overflows no longer answer the purpose of the contemporary flows.

At present, the assessment and monitoring of the surface waters in EU countries is conducted in accordance to the requirements of the EU Water Framework Directive. Good ecological status of the surface waters (rivers, lakes, transitional waters, coastal water) is defined in Annex $\mathrm{V}$ of the Water Framework Proposal, in terms of the quality of the biological community, the hydrological characteristics and the chemical characteristics. 
In the case of heavily modified or artificial water bodies such as dam reservoirs, the socalled ecological potential is estimated. However, there is a problem (not resolved in the Directive) with small water reservoirs, as the water bodies of stagnant water, because they have an area of less than $0.5 \mathrm{~km}^{2}$.

Indicator organisms (such as fish) have often been used to evaluate the intactness of biological systems or to detect anthropogenic pressures impairing the ecosystems and allow for a transparent classification of the ecological status of rivers and streams. Furthermore, results of the monitoring program, including biological, hydromorphologial and physicochemical quality elements provide some detailed indications of anthropogenic stressors affecting ecosystem of rivers and streams. These indications could be used to plan mitigation measures to reduce the effects of anthropogenic pressures (Spänhoff et al. 2012).

The existing and forthcoming EU policies promote the sustainable hydropower development in the coherence with the WFD, and EU environmental legislation clearly consider the ecological impacts on the affected water bodies and the adjacent wetlands (Kougias et al. 2014).

\section{CONCLUSIONS}

1. The occurrence of three new fish species was noted in the Miazga stream: common brown bullhead Ameiurus nebulosus, eel Anguilla anguilla and orfe Leuciscus idus. They are likely to be migrants from the fish farms (bullhead) or come from the stocking activities (eel and orfe).

2. From the historical point of view, the structure of fish species composition has changed; below the dam four species disappeared (dace, brook lamprey, burbot, bleak), and four new species occurred (three-spined stickleback, sunbleak, orfe, eel). Upstream the dam the three-spined stickleback, burbot, weatherfish, roach, crucian carp, and carp disappeared.

3. Shift in the fish assemblage composition may be affected by the pollution of stream, stocking activities, escaping from the fish ponds and impact of the dam reservoir.

4. High abundance of perch and other eurytopic species indicates a worsening of the Miazga stream condition.

5. At most of sites the biotic indices pointed to the stability of the fish fauna assemblages, however at the sites downstream of reservoir the exposition to the stress was noted.

6. Results of the present study should be used to plan mitigation measures to reduce the effects of anthropogenic pressures in Miazga.

7. Impacts of dam reservoirs on small river ecosystem are poorly documented, therefore the further surveys of fish species composition in the small rivers or streams, such as Miazga stream, are still needed.

\section{REFERENCES}

Adamczyk M., Prus P., Wiśniewolski W. 2013. Possibilities of applying the European Fish Index $(E F I+)$ to assess the ecological status of rivers in Poland Sci. Ann. Pol. Angl. Assoc. 26, 21-51.

Allan J.D. 1998. Ekologia wód płynących. Warszawa, PWN. [in Polish] 
Balon E.K. 1990. Epigenesis of an epigeneticist: the development of some alternative concepts on the early ontogeny and evolution of fishes. Guelph Ichthyol. Rev. 1, 1-48.

Bartel R., Wiśniewolski W., Prus P. 2007. Impact of the Włocławek Dam on migratory fish in the Vistula river. Arch. Pol. Fish. 15(2), 141-156.

Bednarek A. 2001. Undamming rivers: A review of the ecological impacts of dam removal. Environ. Manag. 27(6), 803-814.

Biesiadka E., Kowalik W. 1980. Water mites (Hydracarina) of the Western Bieszczady Mountains 1. Stagnant waters. Acta Hydrobiol. 22, 279-298.

Błachuta J., Picińska-Fałtynowicz J., Czoch K., Kulesza K. 2010. Abiotyczne typy rzek w Polsce [Abiotic river types in Poland]. Gosp. Wod. 5, 181-191. [in Polish]

Buras P., Prus P., Szlakowski J., Wiśniewolski W., Ligięza J. 2007. Wpływ zbiornika zaporowego na ichtiofaunę i ekosystem rzeki - przykład zbiornika Wióry, w: Materiały IV Konferencji Naukowo-Technicznej „Błękitny San”, Nozdrzec 20-21 kwietnia 2007 r., [b.w.], 121-143. [in Polish]

Dąbrowski J. 2008. Wpływ zbiornika „Kotliny” na ichtiofaunę rzeki Miazgi. Praca magisterska. Łódź, Uniwersytet Łódzki. [in Polish]

Dukowska M. 2000. Wpływ nizinnego zbiornika zaporowego na biocenozę rzeki. Kraków, Statsoft Polska, 61-69. [in Polish]

Ekosystem zbiornika Siemianówka w latach 1990-2004 i jego rekultywacja. 2006. Red. A. Górniak. Białystok, Wydaw. Uniwersytetu w Białymstoku. [in Polish]

Franssen N.R., Tobler M. 2013. Upstream effects of a reservoir on fish assemblages 45 years following impoundment. J. Fish. Biol. 82, 1659-1670.

Guidelines for the integrated management of the watershed - phytotechnology and ecohydrology. United Nations Environment Programme. Freshwater Management. Ser. no. 5. 2002. Ed. M. Zalewski. Osaka, UNESCO, 188.

Iversen T.M., Kronvang B., Madsen B.L. Markmann P., Nielsen M.B. 1993. Re-establishment of Danish streams: Restoration and maintenance measures. Aquat. Conserv. 3, 73-92.

Jurik L., Húska D., Halászová K., Bandlerová A. 2015. Small water reservoirs - sources of water or problems? J. Ecol. Eng. 16(4), 22-28.

Kajak Z. 1998. Hydrobiologia. Limnologia. Ekosystemy wód śródlądowych. Warszawa, PWN. [in Polish]

Kawecka B., Eloranta P.V. 1994. Zarys ekologii glonów wód słodkich i środowisk lądowych. Warszawa, PWN. [in Polish]

Kondracki J. 1998. Geografia regionalna Polski. Warszawa, PWN. [in Polish]

Kougias I., Patsialis T., Zafirakou A., Theodossiou N. 2014. Exploring the potential of energy recovery using micro hydropower systems in water supply systems. Wat. Util. J. 7, 25-33.

Krebs Ch. 2011. Ekologia. Eksperymentalna analiza rozmieszczenia i liczebności. Warszawa, PWN. [in Polish]

Kruk A. 2007. Role of habitat degradation in determining fish distribution and abundance along the lowland Warta River, Poland. J. Appl. Ichthyol 23, 9-18.

Kurzawski M. 2012. Wpływ piętrzenia nizinnych rzek na biologię wybranych grup owadów. Praca doktorska. Łódź, Uniwersytet Łódzki. [in Polish]

Marszał L., Zięba G., Kruk A., Trzydel M., Tybulczuk S., Pietraszewski D., Galicka W., Janicki B. 2010. Ichtiofauna strumieni w systemie Wisły w mieście Łodzi [Ichthyofauna of streams in the Vistula river system in the city of Łódź]. Acta Univ. Lodz., Folia Biol. Oecol. Suppl. 89-112, http://cejsh.icm.edu.pl/cejsh/element/bwmeta1.element.cejsh-5d6e8de2-b889-4159-9e35-7c9c29c35695. [in Polish]

Mello J.F., Buzas M.A. 1968. An application of cluster analysis as a method of determining biofacies. J. Paleontol. 42(3), 747-758.

Milligan G.W., Cooper M.C. 1988. A study of standardization of variables in cluster analysis. J. Classif. 5, 181-204. 
Penczak T. 1963. Ichtiofauna rzek Wyżyny Łódzkiej i terenów przyległych. Cz. IB. Hydrografia i rybostan Pilicy [Fish fauna of the Łódź Upland rivers and adjacent areas. Part IB]. Hydrography and fish stocks in Pilica]. Acta Hydrobiol. 10, 499-524. [in Polish]

Penczak T. 1967. Biologiczne i techniczne podstawy połowu ryb stałym prądem elektrycznym [Biological and technical base of electrofishing]. Przegl. Zool. 11, 114-131. [in Polish]

Penczak T. 1988. Ichtiofauna dorzecza Pilicy. Cz. I. Przed utworzeniem zbiornika [Fish fauna of the Pilica basin. Part I. Before Dam reservoir construction]. Sci. Ann. Pol. Angl. Assoc. 1, 23-59. [in Polish]

Penczak T. 1989. Ichtiofauna dorzecza Pilicy. Cz. II. Po utworzeniu zbiornika [Fish fauna of the Pilica basin. Part II. After Dam reservoir construction]. Sci. Ann. Pol. Angl. Assoc. 2, 116-186. [in Polish]

Penczak T., Zaczyński A., Marszał L., Koszaliński H. 1995. Monitoring ichtiofauny dorzecza Pilicy. Cz. I. Dopływy [Fish fauna monitoring of the Pilica Basin. Part I. Tributaries]. Sci. Ann. Pol. Angl. Assoc. 8, 5-52. [in Polish]

Penczak T., Galicka W., Kruk A., Zięba G., Marszał L., Koszaliński H., Tybulczuk S. 2007. Ichtiofauna dorzecza Pilicy w piątej dekadzie badań. Cz. II. Dopływy [Fish fauna in the Pilica river system in the fifth decade of study. Part II. Tributaries]. Sci. Ann. Pol. Angl. Assoc. 20, 35-81. [in Polish]

Petts G.E. 1984. Impounded rivers: perspectives for ecological management. Chichester, John Wiley.

Pietraszewski D., Marszał L., Zięba G., Przybylski M., Zieliński P. 2008. Ichtiofauna systemu rzeki Sanny [Fish fauna of the Sanna River System]. Sci. Ann. Pol. Angl. Assoc. 21, 129-146. [in Polish]

Spänhoff B., Dimmer R., Friese H., Harnapp S., Herbst F., Jenemann K., Mickel A., Rohde S., Schönherr M., Ziegler K., Kuhn K., Müller U. 2012. Ecological Status of Rivers and Streams in Saxony (Germany) According to the Water Framework Directive and Prospects of Improvement. Water 4(4), 887-904.

Schiemer F., Keckeis H., Kamler E. 2003. The early life history stages of riverine fish: ecophysiological and environmental bottlenecks. Comp. Biochem. Physiol. Pt. A 133, 439-449.

Syvaranta J., Jones R.I. 2008. Changes in feeding niche widths of perch and roach following biomanipulation, revealed by stable isotope analysis. Freshwater Biol. 53, 425-434.

Traczewska T.M. 2012. Ecological problems of the dam reservoirs in their multi-functionality aspects, in: European Symposium: Anti-flood defence - today's problems, Paris - Orleans 28-30.03.2012. [b.w.], 20-21.

Vannote R.L., Minshall G.W., Cummins K.W., Sedal J.R., Cushing C.E. 1980. The river continuum concept. Can. J. Fish. Aquat. Sci. 37, 130-137.

Water frame directive. 2000. Directive 2000/60/EC of the European Parliament and of the council of 23 October 2000 establishing a framework for community action in the field of water policy. Official Journal of the European Communities L. 327, 1, 2000, http://eur-lex.europa.eu/LexUriServ/ /LexUriServ.do?uri=OJ:L:2000:327:0001:0072:EN:PDF, access: 10.01.2018.

Wiatkowski M., Głowski R., Kasperek R., Kościański S. 2007. Ocena sposobu użytkowania zbiorników zaporowych małej retencji na terenie województwa opolskiego [Characteristic and exploitation of the small dam reservoirs in the Opole voivodeship]. Nauka Przyr. Technol. 1(2), 33-42. [in Polish]

Wiśniewolski W., Augustyn L., Bartel R., Depowski R., Klich M., Kolman R., Witkowski A. 2004. Restytucja ryb wędrownych a drożność polskich rzek. Warszawa, Wydaw. IRS. [in Polish]

Wood J. 1999. How to waste US\$8M. Inter. Water Power Dam Constr. 51(3), 17-18.

Woody C.A. 2010. Fish surveys in headwater streams of the Nushagak and Kvichak river drainages Bristol Bay, Alaska, The Nature Conservancy, http://www.nature.org/media/alaska/awc_dec_2010.pdf, access: 28.01.2017.

Zalewski M., Frankiewicz P. 1994. Biomanipulations as a method of the water quality improve in dams reservoir, in: Integrated approach to protection and development of aquatic ecosystems. Ed. M. Zalewski. Łódź, Biblioteka Monitoringu Środowiska, PIOŚ, 103-114.

Zubala T. 2009. Influence of dam reservoir on the water quality in a small upland river. Ecohydrol. Hydrobiol. 9 (2-4), 165-173. 


\title{
ANALIZA SKŁADU ICHTIOFAUNY W MIAZDZE - STRUMIENIU ZABLOKOWANYM MAŁYM ZBIORNIKIEM ZAPOROWYM (DORZECZE PILICY, CENTRALNA POLSKA)
}

\begin{abstract}
Streszczenie. Badania ichtiofauny przeprowadzono w strumieniu Miazga, położonym w dorzeczu Pilicy, zablokowanym zaporą bez przepławki dla ryb. Wybrano trzy stanowiska powyżej i dwa poniżej zbiornika. Stwierdzono obecność 13 gatunków ryb i jeden gatunek minoga w stadium larwalnym. Najliczniejsze gatunki to: okoń Perca fluviatilis, kiełb Gobio gobio i karaś srebrzysty Carassius gibelio. Odnotowano obecność trzech nowych gatunków ryb: sumika karłowatego Ameiurus nebulosus, węgorza Anguilla anguilla i jazia Leuciscus idus. Analiza wskaźnika równomierności $(\mathrm{J}$ ') wykazała, że liczba gatunków na stanowiskach zbliżona była do maksymalnej. Stosunkowo mała wartość wskaźnika dominacji D wykazała, że badane zespoły ryb nie były bardzo zdominowane przez jeden gatunek, co potwierdza indeks różnorodności. Różnice w składzie ichtiofauny w miejscach powyżej i poniżej zbiornika zaporowego nie były wystarczająco widoczne $w$ analizie skupień, natomiast $z$ historycznego punktu widzenia struktura ichtiofauny w Miazdze uległa zmianie. Na tę zmianę mogły wpłynąć również inne czynniki antropogeniczne, takie jak zanieczyszczenie strumienia, zarybienia na potrzeby wędkarzy czy położone w pobliżu strumienia stawy rybne.
\end{abstract}

Słowa kluczowe: strumień Miazga, centralna Polska, zbiornik zaporowy, gatunki ryb, wskaźniki biotyczne.

The authors would like to thank Professor Tadeusz Penczak, Dr Lidia Marszat, Professor Mirosław Przybylski and all staff of the Department of Ecology and Vertebrate Zoology, University of Lodz for helping in research and preparing a MSc Thesis, which was a basis for the manuscript. Research was funded from within the own resources of the Department of Ecology and Vertebrate Zoology UL. 